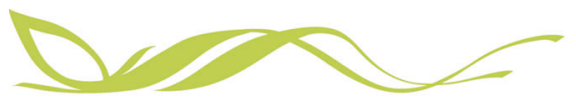

COMMUNICATIONS

ARTICLE

https://doi.org/10.1038/s43247-020-00078-3 OPEN

\title{
The radius of the umbrella cloud helps characterize large explosive volcanic eruptions
}

Robert Constantinescu ${ }^{1 凶}$, Aurelian Hopulele-Gligor ${ }^{2}$, Charles B. Connor ${ }^{1}$, Costanza Bonadonna (D) ${ }^{3}$, Laura J. Connor ${ }^{1}$, Jan M. Lindsay ${ }^{4}$, Sylvain Charbonnier ${ }^{1} \&$ Alain C. M. Volentik ${ }^{5,1}$

Eruption source parameters (in particular erupted volume and column height) are used by volcanologists to inform volcanic hazard assessments and to classify explosive volcanic eruptions. Estimations of source parameters are associated with large uncertainties due to various factors, including complex tephra sedimentation patterns from gravitationally spreading umbrella clouds. We modify an advection-diffusion model to investigate this effect. Using this model, source parameters for the climactic phase of the 2450 BP eruption of Pululagua, Ecuador, are different with respect to previous estimates (erupted mass: 1.5-5 $\times$ $10^{11} \mathrm{~kg}$, umbrella cloud radius: 10-14 km, plume height: 20-30 km). We suggest large explosive eruptions are better classified by volume and umbrella cloud radius instead of volume or column height alone. Volume and umbrella cloud radius can be successfully estimated from deposit data using one numerical model when direct observations (e.g., satellite images) are not available.

\footnotetext{
${ }^{1}$ School of Geosciences, University of South Florida, Tampa, FL, USA. ${ }^{2}$ Private address, Cluj-Napoca, Romania. ${ }^{3}$ Department of Earth Sciences, University of Geneva, Geneva, Switzerland. ${ }^{4}$ School of Environment, University of Auckland, Auckland, New Zealand. ${ }^{5}$ ExxonMobil, Spring, TX, USA.

${ }_{\text {email: }}$ robert.constantinescu00@gmail.com
} 
T he main evidence for past volcanic eruptions' size and intensity comes from the interpretation of their tephra deposits. Explosive eruptions can be compared by volume of tephra erupted, which varies by many orders of magnitude and creates impacts on local to continental scales. High mass flow rates, associated with high volcanic plumes, cause tephra to disperse widely, resulting in gradual thinning of deposits and gradual fining in granulometry of deposits with distance from the volcanic vent. Volcanic hazard assessments place a premium on the interpretation of deposits because they inform us about the nature of the past activity and help forecast future eruptions. The better we can reconstruct the nature of past eruptions from deposit data, the better we can anticipate potential future volcanic hazards.

The challenge is to estimate eruption source parameters (ESPs) from the geological interpretation of deposits. ESPs include erupted volume and mass, plume height, total grain-size distribution, mass flow rate, and eruption duration. Eruption volume is commonly estimated using alternative statistical models (e.g., exponential, power-law, or Weibull distribution) to describe the thinning of a tephra deposit with distance from the vent ${ }^{1-7}$. Plume height can be estimated from the distribution of the largest lithic or pumice clasts in the deposit and plume dynamics ${ }^{8-10}$, and is typically used to derive the mass flow rate ${ }^{11-13}$. However, statistical methods used to estimate eruption volume and column height are sensitive to deposit erosion ${ }^{14}$. In particular, older deposits are often eroded, reworked, or sparsely sampled, leading to uncertainty and bias in volume and column height estimates ${ }^{15,16}$, which may result in misclassification of older eruptions ${ }^{17}$.

Numerical models of tephra dispersal and sedimentation attempt to address potential bias using the advection-diffusion equation to estimate ESPs, by matching observed deposit features with numerical model output ${ }^{18-22}$. Using inversion techniques, deposit data (i.e., mass per unit area, thickness, local grain-size distribution) are used to estimate the erupted mass, plume height, and total grain-size distribution ${ }^{5,18,19,23-26}$. One advantage of these models is that they can better estimate ESPs with uncertainty quantification ${ }^{25,27}$.

Success in estimating ESPs is evaluated based on how well the model, statistical or numerical, fits the observed data ${ }^{18,23-30}$. However, model assumptions, again either statistical or numerical, also may lead to biased estimates of ESPs. In particular, many numerical models assume that tephra is released from either a point, a vertical line atop the volcano or as diffusion along a vertical line ${ }^{18-21,30,31}$ and that the deposit thins monotonically from the vent, with the exception of secondary maxima associated with ash aggregation or local topography and low atmosphere wind fields ${ }^{7,32-37}$. Large explosive eruption plumes deviate significantly from these simplified plume geometries by producing laterally spreading umbrella clouds around the level of neutral buoyancy ${ }^{13,38-44}$. A laterally spreading cloud transports a large volume of tephra rapidly away from the volcano in all directions, reaching radii of $10-100 \mathrm{~s}$ of kilometers and markedly changing the distribution of tephra on the ground.

If the lateral spreading of the umbrella cloud is not taken into account, other ESPs estimated with the numerical model must compensate, resulting in biased estimates of their values. For example, advection-diffusion models may overestimate eruption column height from deposits if the gravitational spreading of umbrella clouds is not accurately described in the model ${ }^{26,28,45}$. Diffusion itself, represented in most models by a diffusion coefficient, may be overestimated to compensate for the rapidly spreading umbrella cloud ${ }^{26}$. We address this issue by modifying the advection-diffusion algorithm of tephra sedimentation in
Tephra $2^{19,23}$, to model particle release from a disk source rather than from a vertical source. The disk model infers the geometry of the laterally spreading cloud and refines the estimate of eruption volume.

Here we show how to estimate the radius of the umbrella cloud from tephra deposits, thus improving our estimation of other ESPs, using data from the climactic phase deposit of the $2450 \mathrm{BP}$ eruption of Pululagua (Ecuador) as a case study. We find that an erupted mass between $1.5-5 \times 10^{11} \mathrm{~kg}$, umbrella cloud radius between 10 and $14 \mathrm{~km}$, and eruption column height of 20-30 km can describe the thinning of the Pululagua deposit with distance from the vent. This modeling effort suggests that observed variations in the thickness of tephra deposits of large eruptions are better modeled using a disk source and that the radius of the umbrella cloud, rather than the height of the erupting column, is the primary factor controlling the sedimentation. A tephra advection-diffusion-sedimentation model using a disk source can be successfully used to estimate eruption volume, plume height, and umbrella cloud radius, reducing parameter compensation, and reducing uncertainty.

This outcome has potential implications for how volcanic eruptions are classified and used to compile hazard scenarios. The Volcanic Explosivity Index (VEI) ${ }^{46,47}$ is a commonly applied scale that uses volume to classify eruptions on a binned quasilogarithmic scale (VEI 0-8) and provides indications of the plume height. We propose that the VEI scale be updated to include the umbrella cloud radius as a metric to characterize large explosive eruptions, acknowledging that any single ESP cannot completely categorize the nature of large explosive eruptions.

\section{Results}

Estimation of the optimal ESPs for Pululagua. The 2450 BP caldera-forming event of Pululagua was a Plinian eruption of dacitic composition, that, allegedly, occurred in a negligible wind field (Supplementary Note $1^{26,48}$ ). Previous studies of the stratigraphic sequence of this eruption ${ }^{26,48}$ indicate the activity started with small phreatomagmatic explosions followed by three Plinian phases overlain by a final fine ash layer. Although the isopach maps of some eruptive phases suggest deposition under a slight north-westerly wind, the near-circular isopach map of the climactic phase indicates deposition in still atmosphere. This conclusion is also supported by the deposition of the uniform fine ash layer at the end of the eruption. The fine ash has a longer settling time, which would have made it susceptible to dispersion in a disturbed atmosphere. We assume the previous interpretations of the eruptive conditions of the climactic phase were correct and model the tephra data set collected by Volentik et al. ${ }^{26}$ using a disk source (Fig. 1) and invert for optimal ESPs using a grid search, which is appropriate given the limited number of model parameters.

Our simulations with a disk source yield a range of ESPs that explain thickness variation of the deposit: a mass estimate of $1.5-5 \times 10^{11} \mathrm{~kg}$ (i.e., a bulk volume of $0.15-0.5 \mathrm{~km}^{3}$, for a deposit density of $1000 \mathrm{~kg} \mathrm{~m}^{-326}$ ), umbrella cloud radius of $10-14 \mathrm{~km}$ and an eruption column height ranging between $20-30 \mathrm{~km}$ (Fig. 2a). We use the chi-square cost function for the goodness of fit for which a value closer to 0 indicates a better agreement between the field measurements and modeled data. We find that a mass of $2.5 \times 10^{11} \mathrm{~kg}\left(0.25 \mathrm{~km}^{3}\right)$, an umbrella cloud radius of $10 \mathrm{~km}$, an eruption column height of $25 \mathrm{~km}$, and a diffusion coefficient of $9500 \mathrm{~m}^{2} \mathrm{~s}^{-1}$, give a best fit for the distribution of data and yield a VEI 4 classification for the eruption. This range of erupted mass and volume are consistent with estimates by other statistical and numerical methods (Supplementary Note 1 and Supplementary Table 1$)^{26}$. 


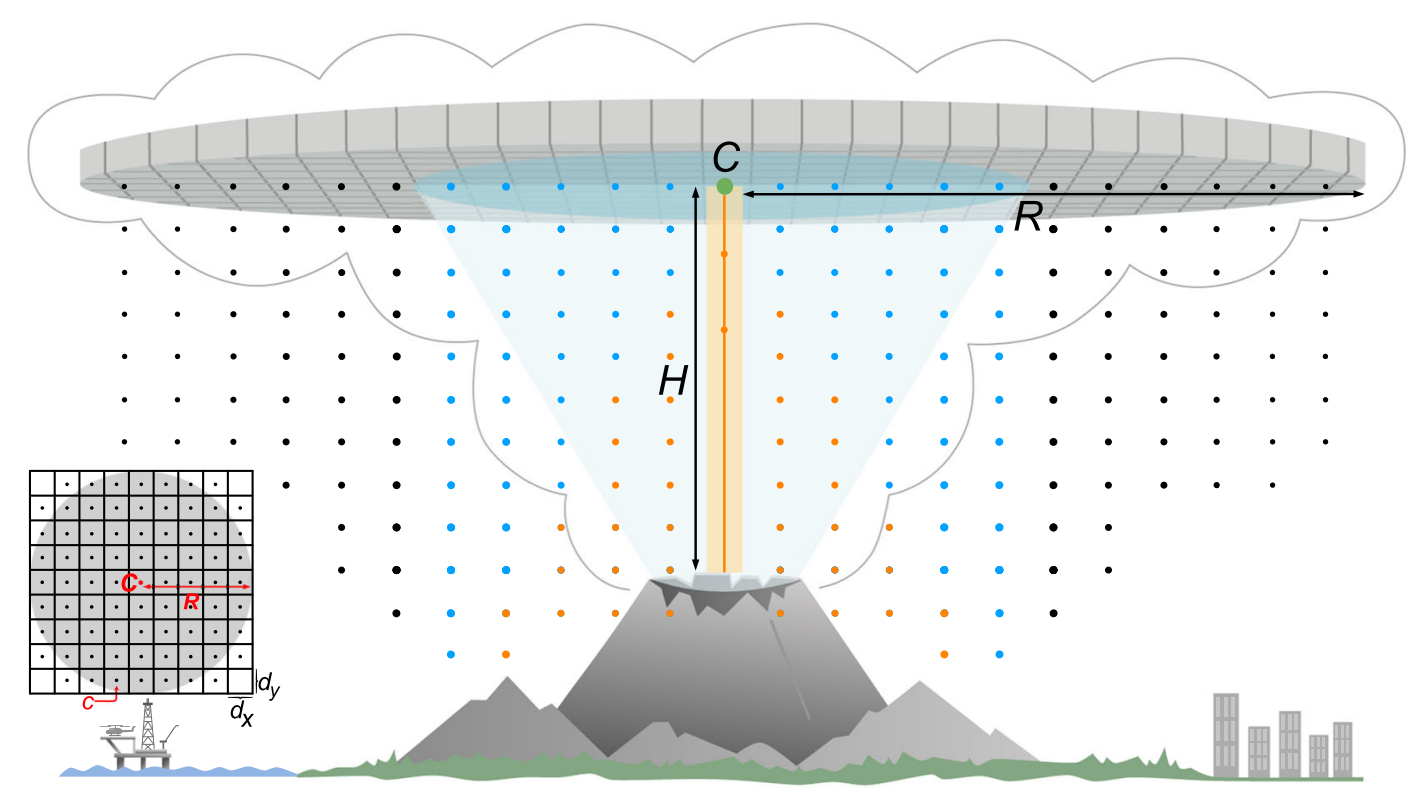

Fig. 1 Schematic representation of an idealized umbrella cloud. The umbrella cloud is represented as a disk of uniform thickness and density, discretized in equally spaced grid cells $\left(d_{x}=d_{y}\right)$ of equal mass fractions (gray disk) (see "Methods" section). Tephra is released from the center of each grid cell within this disk (lowercase $\mathrm{c}$ in inset). Other source geometries are represented as a point source (green dot labeled $C$ ), line source (orange dots stacked along a vertical line), and diffusion along a vertical line (blue inverted cone). $H$ is the tephra release height (disk height), $C$ is the center of the disk, and $R$ the disk radius, corresponding to the radius at which wind velocity exceeds radial spreading velocity. The different models of tephra fallout from different source geometries are represented by dots of different colors. Note, also, the relative dispersion of particles from their respective source geometries (not to scale). The inset figure represents a $2 \mathrm{D}$ view from above of the disk source, resembling the umbrella cloud.


Fig. 2 Tephra thickness with distance from vent. a The plot shows the minimum and maximum range (shaded area) of erupted mass $(M)$, disk height $(H)$, and umbrella cloud radius $(R)$ that can explain the mapped deposit of the climactic phase of the Pululagua 2045 BP eruption. The red dashed line shows the best-fit model. Thickness of the deposit was obtained from mass/area using a bulk deposit density of $1000 \mathrm{~kg} \mathrm{~m}^{-326}$. The $\chi^{2}$-criterion for the goodness of fit is 9300 and 3600 for the maximum and minimum of the estimated range of ESPs, respectively, while for the best fit is 1800 (a value closer to 0 indicating a better agreement between observed and modeled data). $\mathbf{b}$ The relationship between the observed and modeled tephra deposit thickness. The dashed line represents a correlation of 1 and the solid line represents the best fit between the observed and modeled data. Both root mean square error (RMSE) and the coefficient of determination $\left(r^{2}\right)$ indicate the quality of fit between the modeled and observed thicknesses.

Assessment of the model's fit. We evaluate model performance using all data from measured stratigraphic sections of the deposit (Fig. 2b). The regression model shows a coefficient of determination of 0.71 and a coefficient of correlation of 0.84 . Ideally, the modeled data should fit the observed data perfectly and yield a slope of 1 ; the best-fit line slope in our case, 0.68 (95\% confidence interval 0.58-0.79) suggests that the model tends to slightly underestimate observed thicknesses, especially for a few large values. Wilcoxon sign and signed-rank tests ${ }^{49}$ are used to assess the frequency with which the residuals are negative or positive (i.e., over- or under-estimations of the thickness of the deposit) and the impact of the outliers on the model fit ${ }^{18,28}$. For the sign 
test, we have 46 negatives out of 72 residuals (observed modeled), which indicates that the model tends to overestimate the deposit thickness. For the signed-rank test, we set a null hypothesis that there is no difference between the observed accumulation and the modeled one ${ }^{18,28}$. For $n=72$ samples, we calculate the sum ranked of the positives $T_{+}=1197$. From this sum, we can estimate the expected value of $E\left(T_{+}\right)$at 1314 and the variance $\operatorname{Var}\left(T_{+}\right)=181, Z=-0.64$ (i.e., $p>0.26$ for a one-tailed hypothesis), higher than the significance level of 0.05 ( $5 \%$ confidence). Thus, our null hypothesis cannot be rejected, and we consider that the over-estimation of the deposit is caused by outliers in the thickest part of the deposit. We conclude that although our model has a tendency to underestimate thickness proximal to the vent, it reasonably reproduces the overall thickness variation of the deposit. This is encouraging considering that over time several processes (i.e., reworking, compaction, erosion of the fines) have affected the thickness of the Pululagua deposit.

Duration for the umbrella cloud emplacement. Several explosive eruptions in recent decades produced large umbrella clouds that spread quickly across vast distances. Satellite measurements at Pinatubo, 1991, showed that the umbrella cloud reached a 280 $\mathrm{km}$ diameter within the first hour of the eruption ${ }^{50}$ yielding a spreading rate of $\sim 4.6 \mathrm{~km} \mathrm{~min}^{-1}$. Although our model does not account for the dynamics of lateral spreading clouds, we can estimate how long it took for the estimated umbrella cloud of Pululagua to reach the model radius. Using models for the rate of a spreading umbrella cloud $40,41,51$ and the previously estimated mass flow rate for Pululagua ${ }^{26}$, we calculate that the umbrella cloud formed in 135-335 s after the onset of the eruption. This yields a $2.5-4.4 \mathrm{~km} \mathrm{~min}^{-1}$ spreading rate for a $10-14 \mathrm{~km}$ radius umbrella cloud. High spreading rates of radial (or asymmetrical) clouds facilitate the transport of coarser tephra particles to larger distances resulting in coarser-grained deposits over vast areas $^{13,52}$; the bulk of particles ejected during a volcanic eruption will fall from this umbrella region ${ }^{13,36}$.

\section{Discussion}

Modeling tephra sedimentation using a disk source geometry provides a better estimation of the ESPs without resorting to the use of highly implausible physical parameters (e.g., very high eruption columns; very high diffusion coefficients). Although still simplified in source geometry, our model results are in agreement with the umbrella cloud model, whereby the bulk of tephra sedimentation occurs in regions directly under the leading edge of the cloud ${ }^{10}$ with sedimentation occurring past this point largely due to atmospheric diffusion. When compared with other source geometries our model provides an overall better fit of the deposit than models without a disk source. We compare the disk source with a point and vertical line sources in Fig. 3. For this comparison, we keep identical input parameters across the three simulations (i.e., erupted mass, total grain-size distribution, diffusion coefficient, and particle release height (Supplementary Table 2)). We find that both point and line sources tend to overestimate deposit thickness near the vent and show exponential decay of thickness with distance from the vent (Fig. 3). In the Pululagua deposit, there is a significant variation in thickness near the vent in different outcrops $(>20 \mathrm{~cm})$ and a slower decay in deposit thickness than expected for exponential thinning. Line and point sources can model this change in deposit thickness with distance from the vent, but only if the model compensates for the narrow source by greatly increasing the diffusion coefficient parameter, thus, smoothing the modeled deposit ${ }^{26,34}$.

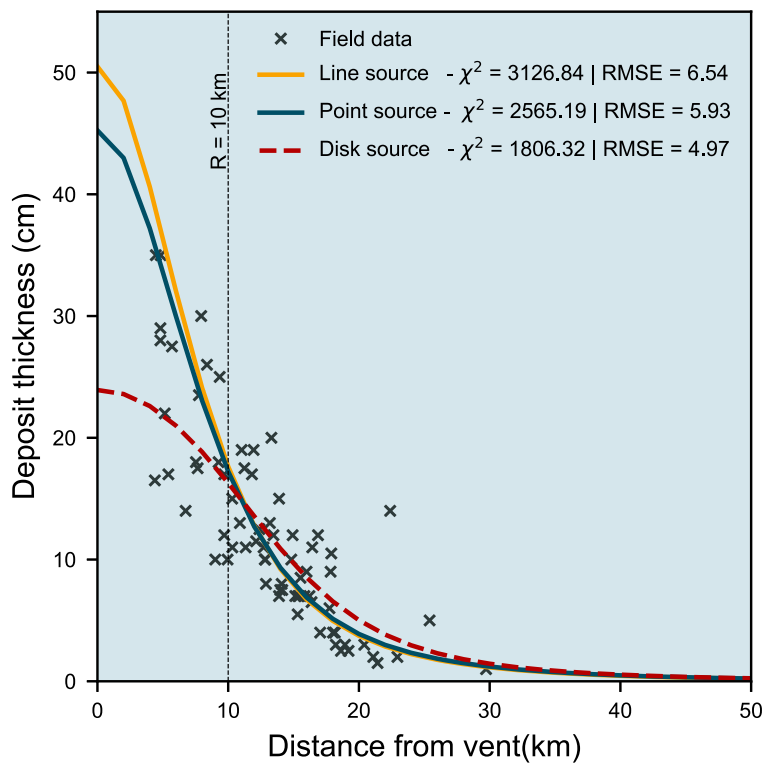

Fig. 3 Sensitivity to source geometry. The difference in thinning of the deposit with radial distance from the vent simulated with a point source, line source, and disk source. The vertical line represents the location of the disk edge (radius). The simulated parameters include mass $(M) 2.5 \times 10^{11}$ $\mathrm{kg}$, column height $(H) 25 \mathrm{~km}$, disk radius $(R) 10 \mathrm{~km}$, and diffusion coefficient (K) $9500 \mathrm{~m}^{2} \mathrm{~s}^{-1}$. The RMSE and the $\chi^{2}$-criterion for the goodness of fit indicate that a better fit of the deposit is obtained by modeling with a disk source, primarily because of better fit at $R<10 \mathrm{~km}$.

The diffusion coefficient is an empirical value used to characterize complex processes occurring in a convective plume and during atmospheric diffusion. Often, the diffusion coefficient in advection-diffusion models is used to increase the dispersal of fine ash in simulations ${ }^{19,26,40}$. Our simulations with a disk source show that high diffusion coefficients (e.g., $>20,000 \mathrm{~m}^{2} \mathrm{~s}^{-1}$ ) underestimate the rate of thinning with distance and produce a flat deposit, whereas lower values (e.g., $<10,000 \mathrm{~m}^{2} \mathrm{~s}^{-1}$ ) fit the observed thinning (Fig. 4a, b). By introducing the disk source, the observed deposit thickness variation is explained without resorting to a very high diffusion coefficient (e.g., $\left.>10^{4} \mathrm{~m}^{2} \mathrm{~s}^{-1}\right)^{53}$.

Modeling the disk radius with a low diffusion coefficient is useful because it allows us to directly estimate the umbrella cloud radius, defined as the radius the cloud reaches before advection is dominated by wind velocity ${ }^{13,52}$. Our model of the Pululagua deposit constrains disk radius within a few kilometers of uncertainty. An umbrella cloud radius of $10-14 \mathrm{~km}$ gives the lowest relative error between the observed and modeled deposit thicknesses (Fig. 2a). We find the model fit is quite sensitive to disk radius; significantly poorer fit is achieved with disk radii that are smaller or larger than this range (Fig. 4a).

Interestingly, introducing the disk radius parameter decreases the model sensitivity to eruption column height. A higher eruption column allows for a longer settling time for finer particles, increasing the distribution of tephra. Our simulations show that a considerable range of eruption column heights (i.e., $10-35 \mathrm{~km}$ ) equally explain deposit thickness within the uncertainty of the observations, especially at distances $>15 \mathrm{~km}$ from the vent (Fig. $4 \mathrm{c}$ ), where the risk to infrastructure and people is likely greater.

We note that sometimes very high volcanic eruption columns (40-60 km, e.g., the Ilopango, Toba, Campanian, and Taupo eruptions) are invoked to explain the observed thinning of very large eruption deposits ${ }^{53-56}$. High eruption columns are required by these models to increase the total fall time of tephra and to explain the slow thinning of the deposit. The properties of the atmosphere 

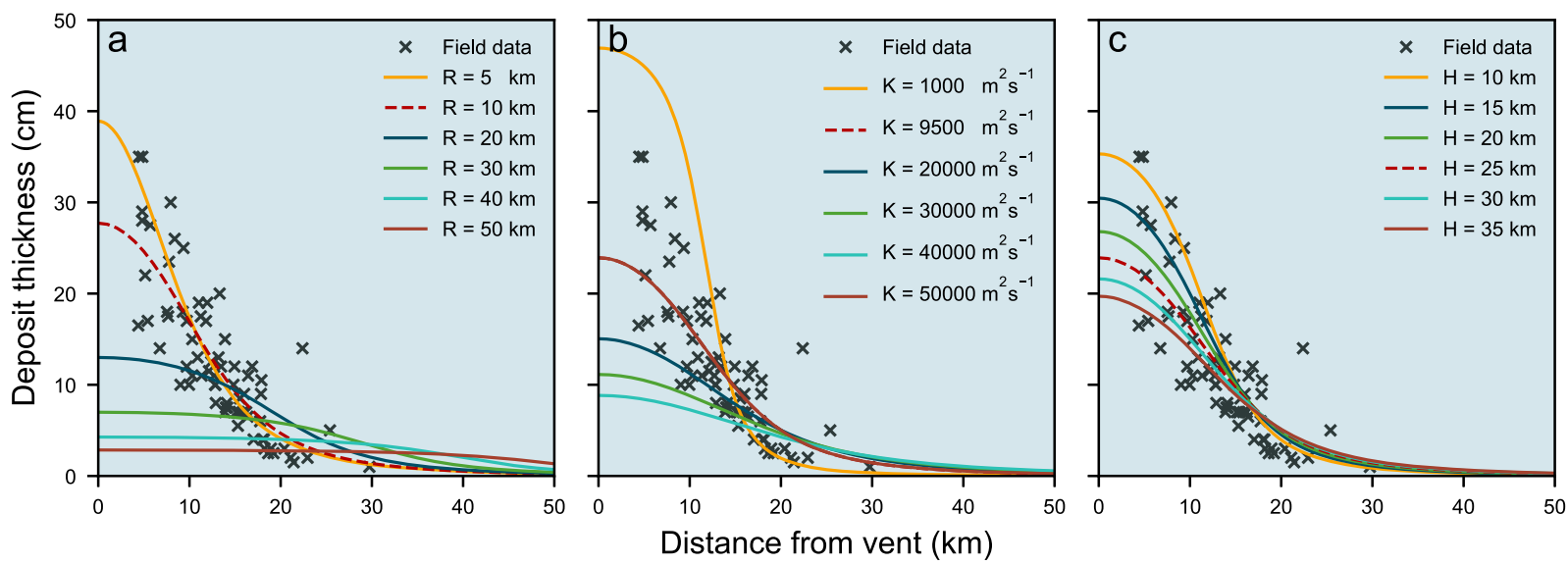

Fig. 4 Sensitivity to eruption source parameters. a The differences in the deposit thinning based on changes in disk radius. $M, H$, and $K$ values are the same used in Fig. 3, only radius, $R$, changes between curves. The $\chi^{2}$-criterion for the goodness of fit for $R=10 \mathrm{~km}$ is 1800 , whereas for $R=5 \mathrm{~km} \chi^{2}$ is 2200. b The thinning of the deposit using different diffusion coefficients $K ; M, H$, and $R$ values are the same as in Fig. 3. c Change in the deposit based on different column (disk) heights: $M, K$, and $R$ are the same as in Fig. 3, only $H$ is varied.

Table 1 Volcanic Explosivity Index updated with umbrella cloud radius as an additional classification criterion.

\begin{tabular}{|c|c|c|c|c|c|c|c|c|c|}
\hline Criteria | VEI & 0 & 1 & 2 & 3 & 4 & 5 & 6 & 7 & 8 \\
\hline Volume of ejecta $\left(\mathrm{m}^{3}\right)$ & $<10^{4}$ & $<10^{6}$ & $<10^{7}$ & $<10^{8}$ & $<10^{9}$ & $<10^{10}$ & $<10^{11}$ & $<10^{12}$ & $>10^{12}$ \\
\hline Column height $(\mathrm{km})$ & $<0.1$ & $0-1$ & $1-5$ & 3-15 & $10-25$ & $>25$ & - & - & - \\
\hline Umbrella cloud radius $(\mathrm{km})$ & - & $<10^{b}$ & $<10^{b}$ & $<10$ & $10-100$ & $100-200$ & $200-500$ & $500-1000$ & $>1000$ \\
\hline
\end{tabular}

Table 2 Umbrella cloud radii and VEI indexes of severala observed and bast eruptions.

\begin{tabular}{|c|c|c|c|}
\hline Eruption & VEI & Volume $\left(\mathbf{k m}^{3}\right)$ & Radius (km) \\
\hline Kelut, Indonesia, 2014 ${ }^{\mathrm{a}}$ & 4 & 0.1 bulk volume 65 & $\sim 40$ (upwind) 66 \\
\hline Cordón Caulle, Chile, 2011a & $4-5$ & $1.1 \pm 0.2$ tephra fallout volume ${ }^{27}$ & 35-60 (crosswind) $)^{27}$ \\
\hline Sarychev Peak, Kurile, Russia, 2009a & 4 & 0.4 bulk volume 68 & $\sim 2569$ \\
\hline Reventador, Ecuador, 2002a & 4 & 0.3 bulk volume ${ }^{73}$ & $\sim 42.5^{71}$ \\
\hline Pinatubo, Philippines, $1991^{a}$ & 6 & $\begin{array}{l}\text { 8.4-10.4 bulk volume } \\
\text { 3.7-5.3 DRE }\end{array}$ & $\sim 250$ (upwind) $)^{75}$ \\
\hline Redoubt, Alaska, U.S., 1990a & 3 & - & $\sim 17$ (co-ignimbrite cloud) $)^{57}$ \\
\hline Mount St. Helens, U.S., 1980a & 5 & $\begin{array}{l}1.3 \text { tephra fallout volume }{ }^{76} \\
0.73 \text { tephra fallout volume }\end{array}$ & $\sim 15$ (upwind) $^{78}$ \\
\hline
\end{tabular}

at these very high altitudes are, however, inconsistent with the particle settling characteristics. Tephra fallout models assume that particles reach their settling velocities as a function of atmospheric density. The atmosphere at very high altitudes has such a low density that particles fall from the high altitude into the denser lower atmosphere before they actually reach their settling velocities. This means that increasing the eruption column height is not actually an effective way to increase tephra dispersion very far from the vent. Instead, we suggest that a disk source model for sedimentation is more consistent with the physics of large explosive eruptions as shown by models for laterally spreading umbrella clouds ${ }^{40-42}$. Previous models for lateral spreading clouds showed the implications the umbrella has for the accountability of tephra fallout at larger distances from the vent in short time periods ${ }^{40,41}$. Using the Ash3D numerical model, Mastin et al. ${ }^{40}$ noted that for large explosive eruptions umbrella clouds control the dispersal of 
tephra in simulations and that simulations are less sensitive to eruption column height. New models to estimate eruption column height from maximum clast dispersal also indicate that the distance traveled by a clast could be explained by a lower lateral spreading cloud instead of a higher sub-vertical plume $e^{8,9}$.

Here we confirm, using field data and a revised numerical model, that observed variations in the thickness of tephra deposits of large eruptions are better explained using a disk source. Our analysis of the Pululagua deposit indicates that the radius of the umbrella cloud, rather than the height of the erupting column, is the primary factor controlling the sedimentation. Furthermore, the diffusion coefficient becomes less important in simulations; the thinning of the deposit is driven mainly by the spreading plume with only the distal portion of the cloud being significantly advected by the wind. Altogether, a tephra advection-diffusion-sedimentation model using a disk source can be successfully used to estimate eruption volume, plume height, and umbrella cloud radius and better account for uncertainties in these ESPs.

Our findings have implications for the way volcanologists evaluate large explosive eruptions and offer improvements to volcanic hazard assessments. We suggest for example that the use of the most common eruption magnitude scale, the $\mathrm{VEI}^{46}$, can be improved by coupling erupted volume and umbrella cloud radius as metrics to characterize and classify large eruptions (e.g., VEI > 4), rather than relying only on eruption column height to classify the intensity of such events. An additional category dedicated to umbrella clouds can be inserted in the VEI scale (Table 1) using radii ranges based on umbrella clouds observed in near real-time satellite imagery data, and values estimated from field deposits of past eruptions (Table 2). Table 1 shows a tentative update to the VEI scale based on a limited number of observed eruptions and existing published estimations of umbrella clouds of past VEI 7 eruptions. This proposed rubric is semi-logarithmic for critical umbrella cloud radii $10-1000 \mathrm{~km}$ as umbrella radius increases more slowly than eruption volume. It is admittedly complicated by factors such as substantial co-pyroclastic density currents plumes from relatively small-volume eruptions (e.g., 1990 Redoubt eruption ${ }^{57}$ ), and tentative due to the current sparsity of plume radii estimates from tephra deposit data.

Based on the Pululagua analysis, umbrella cloud radii can be approximated from field deposits with lower uncertainty than eruption column height, and eruption volume can be estimated simultaneously using a single numerical model. Ultimately, the method presented here can be used to further constrain the relationship between volume and umbrella cloud radii of large eruptions. Subsequently, numerical inversions can be conducted to estimate the ESPs of a sufficient number of large past eruptions to update the VEI scale. At the same time, real-time satellite imagery can be used to extract valuable information on the extension of umbrella clouds of modern eruptions. An updated VEI scale that includes an umbrella cloud radius as a metric for large eruptions would better inform models for tephra sedimentation and make these more robust tools for future hazard assessment.

\section{Methods}

Advection-diffusion-sedimentation model (ADS). We modify the Tephra2 algorithm ${ }^{18,19}$, an Eulerian model that uses the advection-diffusion-sedimentation (ADS) equation $3,14,18,21,58$ to estimate the ground accumulation of particles released from a source above the volcano. The source describes the volcanic plume (i.e., source term) that in sedimentation models comprises a series of empirically derived parameters-total erupted mass $\left(M_{\mathrm{T}}\right)$, total grain-size distribution (TGSD), column height $(H)$. Typically, the source term assumes simplified geometries such a point or a line source, but other geometries have been tested (e.g., horizontal line, disk $\left.{ }^{59}\right)$. We developed a Python algorithm in which we implement a disk-shaped source term to account for large volcanic umbrella clouds observed in nature. The umbrella cloud is inserted as a disk and does not account for the laterally spreading plume dynamics (i.e., not modeling the ash transportation and diffusion within the plume). Instead, we assume the cloud is already emplaced (i.e., the cloud spreading velocity is equal or lower than surrounding wind velocity ${ }^{44}$ ) and the modeling of particles' sedimentation starts with the particles falling under gravity from the height at the base of the cloud ( $H$ in Fig. 1). We refer the reader to Connor et al. ${ }^{23}$ and Bonadonna et al. ${ }^{19}$ for a more detailed description of the equations used in the Tephra2 code, including particle settling velocities and particle mass fraction calculations, which remain unchanged in the Python model. Here we describe the implementation of the umbrella cloud source term.

We assume a well-mixed radially spreading cloud of uniform thickness and density ${ }^{13,44,60,61}$ with a total mass of:

$$
M_{\mathrm{T}}=\pi R^{2} h \eta,
$$

where $R$ is the radius of the umbrella cloud and $\eta$ the mass fraction of tephra in the cloud $^{60}$. Next, we discretize the disk in a number of equally spaced grid cells (Fig. 1, inset). The distribution of particle classes in the cloud is uniform and based on the values published by Volentik et al. ${ }^{26}$. The mass of tephra in each grid cell $\left(m_{c j}\right)$ encompassed within the disk radius will be:

$$
m_{c_{j}}=\frac{M_{\mathrm{T}}}{N_{\mathrm{c}_{j}}},
$$

where $N_{c j}$ is the total number of cells describing the disk.

Once the geometry of the source and the distribution of mass are assigned, the code calculates an analytical solution of the ADS equation by integrating for different particle sizes $(\phi)$ released from the cells describing the umbrella cloud $\left(c_{j}\right)$. We now calculate the accumulation of particles at one point on the ground using:

$$
f_{\mathfrak{c}_{j}, \phi}(x, y)=\frac{S m_{\mathcal{c}_{j}, \phi}}{4 \pi H K} \exp \left[-\frac{\left(x-\left(X_{0}+\frac{u H}{S_{\phi}}\right)\right)^{2}+\left(y-\left(Y_{0}+\frac{v H}{S_{\phi}}\right)\right)^{2}}{4 K \frac{H}{S_{\phi}}}\right],
$$

where $S$ is the particle settling velocity, $K$ is the atmospheric diffusion coefficient and $u, v$ wind field components (direction and speed). In the end, we integrate over a range of particles sizes released from different grid cells and calculate the total mass accumulation of tephra on the ground:

$$
M(x, y)=\sum_{c_{j}=1}^{c_{\max }} \sum_{\phi_{\min }}^{\phi_{\max }} f_{c_{j}, \phi}(x, y) .
$$

Due to the high complexity of the natural processes governing tephra dispersal and deposition, this model is simplified through several assumptions: the surrounding topography is uniform (i.e., flat); particles are released from specific points in the designed disks and fall according to their own settling velocity, which varies with atmospheric density ${ }^{62}$, through an atmosphere with a constant diffusion and no vertical wind.

Tephra transport in umbrella cloud models. We used the density-driven cloud model $13,40,41,51,57$ to see if the umbrella cloud radius obtained from our model can be explained given the estimated mass flow rates reported for Pululagua ${ }^{26}$. We implement in code the following equations to estimate the radius of an umbrella cloud and time of emplacement:

$$
R=\left(\frac{3 \lambda N q}{2 \pi}\right)^{\frac{1}{3}} t^{\frac{2}{3}}
$$

where $\lambda$ is an empirical constant evaluated at $0.2^{41,51}, N$ is Brunt-Väisälä frequency estimated at $0.02^{40,41,51}$. The volumetric flow rate in the umbrella cloud is represented by $q$ and can be estimated using:

$$
q=C \sqrt{k} \frac{M^{\frac{3}{4}}}{N^{\frac{5}{8}}}
$$

where $M$ is the mass discharge rate and $k$ efficiency of air entrainment $t^{40,41,51}$. We used $C=0.5 \times 10^{10} \mathrm{~m}^{3} \mathrm{~kg}^{-3 / 4} \mathrm{~s}^{-7 / 8}$, a proportionality constant for eruptions in tropical regions ${ }^{41,51}$.

\section{Data availability}

The field data used in simulations are available to download at https://github.com/ robertoon/umbrella_cloud_model/tree/main/data, or by request to the corresponding author.

\section{Code availability}

The Python code developed to simulate sedimentation from an umbrella cloud and instructions for its use are available to download at https://github.com/robertoon/ umbrella_cloud_model, or by request to the corresponding author.

Received: 6 July 2020; Accepted: 2 December 2020; Published online: 04 January 2021 


\section{References}

1. Biass, S., Bonadonna, C. \& Houghton, B. F. A step-by-step evaluation of empirical methods to quantify eruption source parameters from tephra-fall deposits. J. Appl. Volcanol. 8, 1 (2019).

2. Daggitt, M. L., Mather, T. A., Pyle, D. M. \& Page, S. AshCalc-a new tool for the comparison of the exponential, power-law and Weibull models of tephra deposition. J. Appl. Volcanol. 3, 7 (2014).

3. Bonadonna, C. \& Costa, A. in Modeling Volcanic Processes: The Physics and Mathematics of Volcanism (eds Lopes, R. M. C., Fagents, S. A., \& Gregg, T. K. P.) 173-202 (Cambridge University Press, 2013).

4. Bonadonna, C. \& Costa, A. Estimating the volume of tephra deposits: a new simple strategy. Geology 40, 415-418 (2012).

5. Bonadonna, C. \& Houghton, B. F. Total grain-size distribution and volume of tephra-fall deposits. Bull. Volcanol. 67, 441-456 (2005).

6. Fierstein, J. \& Nathenson, M. Another look at the calculation of fallout tephra volumes. Bull. Volcanol. 54, 156-167 (1992).

7. Pyle, D. M. The thickness, volume and grainsize of tephra fall deposits. Bull. Volcanol. 51, 1-15 (1989).

8. Rossi, E., Bonadonna, C. \& Degruyter, W. A new strategy for the estimation of plume height from clast dispersal in various atmospheric and eruptive conditions. Earth Planet. Sci. Lett. 505, 1-12 (2019).

9. Burden, R. E., Phillips, J. C. \& Hincks, T. K. Estimating volcanic plume heights from depositional clast size. J. Geophys. Res. 116, https://doi.org/10.1029/ 2011JB008548 (2011)

10. Carey, S. \& Sparks, R. S. J. Quantitative models of the fallout and dispersal of tephra from volcanic eruption columns. Bull. Volcanol. 48, 109-125 (1986)

11. Degruyter, W. \& Bonadonna, C. Improving on mass flow rate estimates of volcanic eruptions. Geophys. Res. Lett. 39, https://doi.org/10.1029/ 2012GL052566 (2012).

12. Mastin, L. G. et al. A multidisciplinary effort to assign realistic source parameters to models of volcanic ash-cloud transport and dispersion during eruptions. J. Volcanol. Geotherm. Res. 186, 10-21 (2009).

13. Sparks, R. S. J. et al. Volcanic Plumes (Wiley, 1997).

14. Bonadonna, C., Costa, A., Folch, A. \& Koyaguchi, T. in The Encyclopedia of Volcanoes 2nd edn (ed. Sigurdsson, H.) 587-597 (Academic Press, 2015).

15. Buckland, H. M., Cashman, K. V., Engwell, S. L. \& Rust, A. C. Sources of uncertainty in the Mazama isopachs and the implications for interpreting distal tephra deposits from large magnitude eruptions. Bull. Volcanol. 82, 23 (2020).

16. Engwell, S. L., Sparks, R. S. J. \& Aspinall, W. P. Quantifying uncertainties in the measurement of tephra fall thickness. J. Appl. Volcanol. 2, 5 (2013).

17. Kiyosugi, $\mathrm{K}$. et al. How many explosive eruptions are missing from the geologic record? Analysis of the quaternary record of large magnitude explosive eruptions in Japan. J. Appl. Volcanol. 4, 17 (2015).

18. Connor, L. J. \& Connor, C. B. in Statistics in Volcanology Vol. 231-242 (eds Mader, H., Coles, S. C., Connor, C. B. \& Connor, L. J.) (Geological Society, 2006).

19. Bonadonna, C. et al. Probabilistic modeling of tephra dispersal: hazard assessment of a multiphase rhyolitic eruption at Tarawera, New Zealand. J. Geophys. Res. 110, https://doi.org/10.1029/2003JB002896 (2005).

20. Macedonio, G., Costa, A. \& Longo, A. A computer model for volcanic ash fallout and assessment of subsequent hazard. Comput. Geosci. 31, 837-845 (2005).

21. Connor Charles, B., Hill Brittain, E., Winfrey, B., Franklin Nathan, M. \& Femina Peter, C. L. Estimation of volcanic hazards from Tephra Fallout. Nat. Hazards Rev. 2, 33-42 (2001).

22. Suzuki, T. in Arc Volcanism: Physics and Tectonics (eds Shimozuru, D. \& Yokoyama, I.) 95-116 (Terra Scientific Publishing, 1983).

23. Connor, C. B. et al. in Volcán de Colima: Portrait of a Persistently Hazardous Volcano (eds Varley, N., Connor, C. B., \& Komorowski, J.-C.) 81-110 (Springer Berlin Heidelberg, 2019).

24. Moiseenko, K. B. \& Malik, N. A. Linear inverse problem for inferring eruption source parameters from sparse ash deposit data as viewed from an atmospheric dispersion modeling perspective. Bull. Volcanol. 81, 19 (2019).

25. White, J. T., Connor, C. B., Connor, L. \& Hasenaka, T. Efficient inversion and uncertainty quantification of a tephra fallout model. J. Geophys. Res. 122, 281-294 (2017).

26. Volentik, A. C. M., Bonadonna, C., Connor, C. B., Connor, L. J. \& Rosi, M. Modeling tephra dispersal in absence of wind: Insights from the climactic phase of the 2450BP Plinian eruption of Pululagua volcano (Ecuador). J. Volcanol. Geotherm. Res. 193, 117-136 (2010).

27. Bonadonna, C. et al. Dynamics of wind-affected volcanic plumes: the example of the 2011 Cordón Caulle eruption, Chile. J. Geophys. Res. 120, 2242-2261 (2015).

28. Magill, C., Mannen, K., Connor, L., Bonadonna, C. \& Connor, C. Simulating a multi-phase tephra fall event: inversion modelling for the 1707 Hoei eruption of Mount Fuji, Japan. Bull. Volcanol. 77, 81 (2015).
29. Mannen, K. Particle segregation of an eruption plume as revealed by a comprehensive analysis of tephra dispersal: theory and application. $J$. Volcanol. Geotherm. Res. 284, 61-78 (2014).

30. Pfeiffer, T., Costa, A. \& Macedonio, G. A model for the numerical simulation of tephra fall deposits. J. Volcanol. Geotherm. Res. 140, 273-294 (2005).

31. Hurst, A. W. \& Turner, R. Performance of the program ASHFALL for forecasting ashfall during the 1995 and 1996 eruptions of Ruapehu volcano. $N$ Z. J. Geol. Geophys. 42, 615-622 (1999).

32. Poulidis, A. P., Takemi, T., Iguchi, M. \& Renfrew, I. A. Orographic effects on the transport and deposition of volcanic ash: a case study of Mount Sakurajima, Japan. J. Geophys. Res. 122, 9332-9350 (2017).

33. Eychenne, J., Rust, A. C., Cashman, K. V. \& Wobrock, W. Distal enhanced sedimentation from volcanic plumes: insights from the secondary mass maxima in the 1992 Mount Spurr fallout deposits. J. Geophys. Res. 122, 7679-7697 (2017)

34. Watt, S. F. L., Gilbert, J. S., Folch, A., Phillips, J. C. \& Cai, X. M. An example of enhanced tephra deposition driven by topographically induced atmospheric turbulence. Bull. Volcanol. 77, 35 (2015).

35. Durant, A. J., Rose, W. I., Sarna-Wojcicki, A. M., Carey, S. \& Volentik, A. C. M. Hydrometeor-enhanced tephra sedimentation: constraints from the 18 May 1980 eruption of Mount St. Helens. J. Geophys. Res. 114, https://doi.org/ 10.1029/2008JB005756 (2009).

36. Sparks, R. S. J., Bursik, M. I., Ablay, G. J., Thomas, R. M. E. \& Carey, S. N. Sedimentation of tephra by volcanic plumes. Part 2: controls on thickness and grain-size variations of tephra fall deposits. Bull. Volcanol. 54, 685-695 (1992)

37. Carey, S. N. \& Sigurdsson, H. Influence of particle aggregation on deposition of distal tephra from the May 18, 1980, eruption of Mount St. Helens volcano. J. Geophys. Res. 87, 7061-7072 (1982).

38. Webster, H. N., Devenish, B. J., Mastin, L. G., Thomson, D. J. \& Van Eaton, A. R. Operational modelling of umbrella cloud growth in a lagrangian volcanic ash transport and dispersion model. Atmosphere 11, https://doi.org/10.3390/ atmos11020200 (2020).

39. Johnson, C. G. et al. Modelling intrusions through quiescent and moving ambients. J. Fluid Mech. 771, 370-406 (2015).

40. Mastin, L. G., Van Eaton, A. R. \& Lowenstern, J. B. Modeling ash fall distribution from a Yellowstone supereruption. Geochem. Geophys. Geosyst. 15, 3459-3475 (2014).

41. Costa, A., Folch, A. \& Macedonio, G. Density-driven transport in the umbrella region of volcanic clouds: Implications for tephra dispersion models. Geophys. Res. Lett. 40, 4823-4827 (2013).

42. Bonadonna, C. \& Phillips, J. C. Sedimentation from strong volcanic plumes. J Geophys. Res. 108, https://doi.org/10.1029/2002JB002034 (2003).

43. Bursik, M. I., Sparks, R. S. J., Gilbert, J. S. \& Carey, S. N. Sedimentation of tephra by volcanic plumes: I. Theory and its comparison with a study of the Fogo A plinian deposit, Sao Miguel (Azores). Bull. Volcanol. 54, 329-344 (1992).

44. Bursik, M. I., Carey, S. N. \& Sparks, R. S. J. A gravity current model for the May 18, 1980 Mount St. Helens plume. Geophys. Res. Lett. 19, 1663-1666 (1992).

45. Poulidis, A. P. et al. Meteorological controls on local and regional volcanic ash dispersal. Sci. Rep. 8, 6873 (2018).

46. Newhall, C., Self, S. \& Robock, A. Anticipating future Volcanic Explosivity Index (VEI) 7 eruptions and their chilling impacts. Geosphere 14, 572-603 (2018).

47. Newhall, C. G. \& Self, S. The volcanic explosivity index (VEI) an estimate of explosive magnitude for historical volcanism. J. Geophys. Res. 87, 1231-1238 (1982).

48. Papale, P. \& Rosi, M. A case of no-wind plinian fallout at Pululagua caldera (Ecuador): implications for models of clast dispersal. Bull. Volcanol. 55, 523 (1993).

49. Wilcoxon, F. Individual comparisons by ranking methods. Biometrics Bull. 1 , 80-83 (1945).

50. Koyaguchi, T. \& Tokuno, M. Origin of the giant eruption cloud of Pinatubo, June 15, 1991. J. Volcanol. Geotherm. Res. 55, 85-96 (1993).

51. Suzuki, Y. J. \& Koyaguchi, T. A three-dimensional numerical simulation of spreading umbrella clouds. J. Geophys. Res. 114, https://doi.org/10.1029/ 2007JB005369 (2009)

52. Baines, P. G. \& Sparks, R. S. J. Dynamics of giant volcanic ash clouds from supervolcanic eruptions. Geophys. Res. Lett. 32, https://doi.org/10.1029/ 2005GL024597 (2005)

53. Matthews, N. E. et al. Ultra-distal tephra deposits from super-eruptions: Examples from Toba, Indonesia and Taupo Volcanic Zone, New Zealand. Quat. Int. 258, 54-79 (2012).

54. Pedrazzi, D. et al. The Ilopango Tierra Blanca Joven (TBJ) eruption, El Salvador: volcano-stratigraphy and physical characterization of the major Holocene event of Central America. J. Volcanol. Geotherm. Res. 377, 81-102 (2019). 
55. Costa, A., J. Suzuki, Y. \& Koyaguchi, T. Understanding the plume dynamics of explosive super-eruptions. Nat. Commun. 9, 654 (2018).

56. Marti, A., Folch, A., Costa, A. \& Engwell, S. Reconstructing the plinian and coignimbrite sources of large volcanic eruptions: a novel approach for the Campanian Ignimbrite. Sci. Rep. 6, 21220 (2016).

57. Woods, A. W. \& Kienle, J. The dynamics and thermodynamics of volcanic clouds: theory and observations from the april 15 and april 21, 1990 eruptions of Redoubt volcano, Alaska. J. Volcanol. Geotherm. Res. 62, 273-299 (1994).

58. Costa, A., Macedonio, G. \& Folch, A. A three-dimensional Eulerian model for transport and deposition of volcanic ashes. Earth Planet. Sci. Lett. 241, 634-647 (2006).

59. Lim, L. L., Sweatman, W. L., McKibbin, R. \& Connor, C. B. Tephra fallout models: the effect of different source shapes on isomass maps. Math. Geosci. 40, 147-157 (2008).

60. Huppert, H. \& Simpson, J. The slumping of gravity currents. J. Fluid Mech. 99, 785-799 (1980).

61. Simpson, J. E. Gravity Currents 244 (Ellis Horwood, 1997).

62. Bonadonna, C., Ernst, G. G. J. \& Sparks, R. S. J. Thickness variations and volume estimates of tephra fall deposits: the importance of particle Reynolds number. J. Volcanol. Geotherm. Res. 81, 173 (1998).

63. Van Eaton, A. R. et al. Volcanic lightning and plume behavior reveal evolving hazards during the April 2015 eruption of Calbuco volcano. Chile Geophys. Res. Lett. 43, 3563-3571 (2016).

64. Castruccio, A. et al. Eruptive parameters and dynamics of the April 2015 subPlinian eruptions of Calbuco volcano (southern Chile). Bull. Volcanol. 78, 62 (2016).

65. Goode, L. R., Handley, H. K., Cronin, S. J. \& Abdurrachman, M. Insights into eruption dynamics from the 2014 pyroclastic deposits of Kelut volcano, Java, Indonesia, and implications for future hazards. J. Volcanol. Geotherm. Res. 382, 6-23 (2019).

66. Hargie, K. A. et al. Globally detected volcanic lightning and umbrella dynamics during the 2014 eruption of Kelud, Indonesia. J. Volcanol. Geotherm. Res. 382, 81-91 (2019).

67. Gudmundsson, M. T. et al. in EGU General Assembly (Vienna, Austria, 2012).

68. Rybin, A. et al. Satellite and ground observations of the June 2009 eruption of Sarychev Peak volcano, Matua Island, Central Kuriles. Bull. Volcanol. 73, 1377-1392 (2011).

69. Pouget, S., Bursik, M., Webley, P., Dehn, J. \& Pavolonis, M. Estimation of eruption source parameters from umbrella cloud or downwind plume growth rate. J. Volcanol. Geotherm. Res. 258, 100 (2013).

70. Larsen, J. F., Śliwiński, M. G., Nye, C., Cameron, C. \& Schaefer, J. R. The 2008 eruption of Okmok Volcano, Alaska: Petrological and geochemical constraints on the subsurface magma plumbing system. J. Volcanol. Geotherm. Res. 264, 85-106 (2013)

71. Chakraborty, P., Gioia, G. \& Kieffer, S. W. Volcanic mesocyclones. Nature 458, 497-500 (2009)

72. Tupper, A. et al. Facing the challenges of the international airways volcano watch: the 2004/05 eruptions of Manam, Papua New Guinea. Weather Forecast. 22, 175-191 (2007).

73. Hall, M. et al. Volcanic eruptions with little warning: the case of Volcán Reventador's Surprise November 3, 2002 Eruption, Ecuador. Rev. Geol. Chile 31, 349-358 (2004).

74. Self, S., Zhao, J.-X., Holasek, R. E., Torres, R. C. \& King, A. J. in Fire and Mud: Eruptions and Lahars of Mount Pinatubo, Philippines (eds Newhall, C. G. \& Punongbayan, R. S.) 1126 (PHIVOLCS, University of Washington Press, U.S. Geological Survey, 1996).

75. Koyaguchi, T. \& Tokuno, M. Origin of the giant eruption cloud of Pinatubo, June 15, 1991. J. Volcanol. Geotherm. Res. 55, 85-96 (1993).

76. Rose, W. I. \& Hoffman, M. F. Distal ashes of the May 18, 1980 eruption of Mount St. Helens. Trans. Am. Geophys. Union Eos. 61, 1137 (1980).
77. Sarna-Wojcicki, A. M., Shipley, S., Waitt, J. R., Dzurisin, D. \& Wood, S. H. Areal Distribution Thickness, Mass, Volume, and Grain-size of Airfall Ash from the Six Major Eruptions of 1980. Report No. 1250, 577-600 (USGS, 1981).

78. Sparks, R. S. J., Moore, J. G. \& Rice, C. J. The initial giant umbrella cloud of the May 18th, 1980, explosive eruption of Mount St. Helens. J. Volcanol. Geotherm. Res. 28, 257-274 (1986).

79. Self, S., Gertisser, R., Thordarson, T., Rampino, M. R. \& Wolff, J. A. Magma volume, volatile emissions, and stratospheric aerosols from the 1815 eruption of Tambora. Geophys. Res. Lett. 31, https://doi.org/10.1029/2004GL020925 (2004).

\section{Acknowledgements}

This research was partially supported by a grant from the U.S. National Science Foundation (NSF 1841928). We acknowledge Mauro Rosi for assisting in the collection of tephra fallout data used in our analysis. R.C. thanks Corneliu C. for assistance with the artwork.

\section{Author contributions}

All authors contributed to writing the paper and participated in the interpretation and discussions of the results. R.C., A.H.-G., and C.C. developed the new code and conducted numerical modeling. C.C., L.J.C, and C.B. wrote the original Tephra2 code upon which this new model is based. A.C.M.V., with assistance from C.C., C.B., and L.J.C, collected and analyzed the field samples we used in this study and conducted the initial estimation of the erupted volume for the deposit of the climatic phase of Pululagua. J.M.L. and S.C. participated in the interpretations of the results and the development of the updated Volcanic Explosivity Index.

\section{Competing interests}

The authors declare no competing interests.

\section{Additional information}

Supplementary information is available for this paper at https://doi.org/10.1038/s43247020-00078-3.

Correspondence and requests for materials should be addressed to R.C.

Peer review information Primary handling editor: Joe Aslin

Reprints and permission information is available at http://www.nature.com/reprints

Publisher's note Springer Nature remains neutral with regard to jurisdictional claims in published maps and institutional affiliations.

\begin{abstract}
cc) (i) Open Access This article is licensed under a Creative Commons BY Attribution 4.0 International License, which permits use, sharing, adaptation, distribution and reproduction in any medium or format, as long as you give appropriate credit to the original author(s) and the source, provide a link to the Creative Commons license, and indicate if changes were made. The images or other third party material in this article are included in the article's Creative Commons license, unless indicated otherwise in a credit line to the material. If material is not included in the article's Creative Commons license and your intended use is not permitted by statutory regulation or exceeds the permitted use, you will need to obtain permission directly from the copyright holder. To view a copy of this license, visit http://creativecommons.org/ licenses/by/4.0/.
\end{abstract}

(C) The Author(s) 2021, corrected publication 2021 